\title{
The Literalist and Fundamentalist Interpretation of the Bible: A Review
}

\author{
Caleb Olayiwola Alu' (i) \\ 1 Department of Religious Studies, Adeleke University, Ede, Nigeria.
}

\begin{abstract}
It is undebatable that Christians and Bible scholars accept the Bible as the uniting point for all - as a source and reference point. However, the approach to interpretation - how they see and read the Bible - divides them. The review of literalist and fundamentalist interpretative approaches based on their identifying tag reveals their convergent and divergent positions. This study shows that no particular hermeneutical "method" can guarantee a better understanding of and obedience to Holy Scripture. An openness of heart and a searching mind remain essential. Also, a large part of the Bible makes sense when read literally and it exercises control on the imagination.
\end{abstract}

Keywords: Literalist, Fundamentalist, Interpretation, Bible

\author{
Correspondence: \\ Caleb Olayiwola Alu \\ Email: alucaleb@gmail.com \\ Manuscript \\ Received 18th September 2020, \\ Accepted 23rd October 2020, \\ Published online 14th December \\ 2020.
}

\section{INTRODUCTION}

This is a study that evaluates the hermeneutical impact of the literalist and fundamentalist interpretation of the Bible, by studying the belief factors that necessitate their approach and practice. Christians and Bible scholars accept the Bible as the uniting point for all - as a source and reference point. Despite this agreement, its interpretation divides them. "Conflict about how to see and read the Bible is the single greatest issue dividing Christians today." According to Oladejo, the Bible is concurrently the meeting point and the departure point of all Christians. ${ }^{2}$ This suggests reasons for various interpretation methods and approaches to Biblical hermeneutics, based on the presupposition majorly determined by its interpreters. This work studies the literalist and fundamentalist approach to the interpretation of the Bible; why they adopted their methods and Christian bodies that practice these interpretations.

\section{FOUNDATION OF BIBLICAL INTERPRETATION}

The word hermeneutics is said to have its origin in the name Hermes. ${ }^{3}$ However, Ramm traced the etymology of the term "hermeneutics" to the Hebrew words Pathar (to interpret) and pithron (an interpretation); and the Greek words hermeneia (interpretation) and harmonius (to interpret), were used in various forms in the New Testament. ${ }^{4}$ Jeanrond, defines hermeneutics as "a theory of interpretation which contains all reflections on methods of biblical interpretation." 5 Bultmann however sees hermeneutics as "the art of scientific understanding." ${ }^{6}$ For Heinrici, it is "the theory of the

\footnotetext{
2 James D. G. Dunn, The Partings of the Ways: Between Christianity and Judaism and Their Significance for the Character of Christianity, (Philadelphia:Trinity Press International, 1991) cited in Marcus J. Borg, Reading the Bible Again for the First Time: Taking the Bible Seriously but not Literally (Harper Collins Publishers, 2001), 3.

3 Olusayo B. Oladejo "Biblical hermeneutics and decision-making: A critique of the dispensationalist approach." International Journal of Current Research, 8, no 2 (2016): 27039-27043.

4 Henry A. Virkler and Karelynne Gerber Ayayo, Hermeneutics: principles and processes of Biblical interpretation $2^{\text {nd }}$ ed., (Grand Rapids, MI: Bakers Academic, 2007),15-16; the Greek god who served as messenger for the gods, transmitting and interpreting their communications to their fortunate, or often unfortunate, recipients.

5 Bernard. Ramm, Protestant Biblical Interpretation,(Boston: W. A. Wilde Company, 1956) cited in Olusayo B. Oladejo, "Biblical hermeneutics and decisionmaking." 27039.

6 Werner G. Jeanrond, “Hermeneutic.” A Dictionary of Biblical Interpretation, R. J. Coggins and J. L. Houlden (Eds.), (Philadelphia: Trinity Press, 1990), 282 cited in Olusayo B. Oladejo, "Biblical hermeneutics and decision-making: A critique of the dispensationalist approach." 27039.

7 Rudolf Bultmann, "Das Problem der Hermeneutik," in Glauben und Verstehen, II, 2d ed.,211-35. TÜbingen, Cited in Gerhard Maier, Biblical Hermeneutics, translated by Robert W. Yarbrough (Wheaton, Il: Crossway, 1994) 16.
} 
interpretation of that which has been handed down." " Some scholars, like Terry and Allen however see hermeneutics beyond the science of study, but rather "the science and art of interpretation"

The special task of hermeneutics is to point out how the differences or the distance between an author and his readers may be removed, ${ }^{9}$ hence to better understand the content, the readers need to transpose themselves into the time and spirit of the author. Therefore, Hermeneutics enables one to move from text to context, to allow the God-inspired meaning of the Word to speak today with a fresh and dynamic relevance as it had in its original setting. ${ }^{10}$

\section{CONTROVERSIAL ISSUES IN CONTEMPORARY HERMENEUTICS}

Throughout the centuries since God revealed the Scriptures, there have been a number of approaches to the study of God's Word. ${ }^{11}$ Understanding these methods "can serve as a warning against repeating some errors of the past." 12 Contemporary interpreters approach the Bible from many directions and produce different results. A truly comprehensive survey of controversial issues in biblical interpretation might be of help to summarize the history of interpretation. Virkler and Ayayo's enumeration will be a background to these issues, yet pivotal to biblical hermeneutics.

\section{Validity in Interpretation}

Hirsch, in his volume Validity in Interpretation, discusses the philosophy that has been gaining acceptance since the 1920s: the belief that "the meaning of a text is what it means to me." 13 Before now, the general belief had been that a text means what its author meant. The study of "what a text says" became the study of "what it says to an individual critic." 14 It became a serious hermeneutical issue, as usurping has led to some of the present day theoretical confusion when a scholar pushed aside the original author and usurped his or her position as the determiner of meaning.

\section{Double Authorship and Sensus Plenior}

The second controversy in hermeneutical study is the double author issue. The question of whether Scripture has a fuller sense (referred to as sensus plenior) than that intended by the human author has been debated for centuries. This term was popularized by Raymond E. Brown, a catholic scholar during the $20^{\text {th }}$ century. He defined it as follows: "The sensus plenior is that additional, deeper meaning, intended by God but not intended by the human author, is seen to exist in the words of a biblical text (or group of texts, or even a whole book) when they are studied in the light of further revelation or development in the understanding of revelation." ${ }^{15}$ However, Brown himself, before the end of his life, was unable to use the method as a viable hermeneutic for scriptural interpretation and ended up rejecting it as too problematic.

Brown states that the literal meaning comes from historical-grammatical analysis, while sensus plenior is not intended by the human author, rather by God. ${ }^{16}$ This interpretative debate is still ongoing. ${ }^{17}$

\section{Literal, Figurative, and Symbolic Interpretations of Scripture}

The third controversial issue in contemporary hermeneutics involves the literalness with which the words of Scripture are interpreted. ${ }^{18}$ In the words of Ramm, conservative Christians are sometimes accused of being "wooden-headed literalists" in their interpretations. ${ }^{19}$ Whereas, some liberal theologians claim that events such as the fall, the flood, and Jonah's story undersea should be interpreted symbolically as they are not supposed to be literal events. However, this view may be born out of higher criticism where anything not scientifically proven is termed fake or symbolical, for example, miracles, the creation story, etc., "If the author meant them to be interpreted literally, we err if we interpret

\footnotetext{
Gotthard Heinrici, "Hermeneutik, biblische," RE 7 (1899): 718-50 cited in Gerhard Maier, Biblical Hermeneutics, $16-17$.

9 Milton S. Terry, Biblical Hermeneutics: A Treatise on the interpretation of the Old and New Testaments (New York: Phillips \& Hunt, 1885), 20; Stuart Allen, The Interpretation of Scripture (London: The Berean Publishing, 1967), 6.

9 Cf., L. Berkhof, Principles of Biblical Interpretations (Grand Rapids, MI: Baker House, 1969), 11; Paul Ricoeur, “The Hermeneutical Function of Distanciation." PhTod 17 (1973): 112-41.

10 Grant R. Osborne, The Hermeneutical Spiral: A Comprehensive Introduction to Biblical Interpretation $2^{\text {nd }}$ ed.(Downers Grove, Il: InterVarsity Press, 2006$), 23$.

11 Henry A. Virkler and Karelynne Gerber Ayayo, Hermeneutics: principles and processes of Biblical interpretation $2^{\text {nd }}$ ed., 43; cf., William Yarchin, History of Biblical Interpretation: A Reader, (Grand Rapids, MI: Baker Academic, 2011),xi .

12 Walter C. Kaiser Jr, "A short History of Interpretation" in Introduction to Biblical Hermeneutics: The Secret for Meaning, rev. and exp., Walter C. Kaiser and Moises Silva, 257-274 (Grand Rapids: Zondervan, 2007), 257; cf. Milton S. Terry, Biblical Hermeneutics: A treatise on the interpretation of the Old and New Testaments, 31 .

13 Eric D. Hirsch, Validity in Interpretation (New Haven: Yale University Press, 1967), 1 cited in Henry A. Virkler and Karelynne Gerber Ayayo, Hermeneutics: principles and processes of Biblical interpretation $2^{\text {nd }}$ ed., 23

14 Hirsch, validity in interpretation, 3.

15 Raymond Edward Brown, The Sensus Plenior of Sacred Scripture, (Eugene, OR: Wipf \& Stock, 2008), 92. However, Brown himself, before the end of his life, ended up "rejecting it as too problematic," unable to be used as a "viable hermeneutic for scriptural interpretation." - Matthew Dunn, "Raymond Brown and the Sensus Plenior Interpretation of the Bible," Studies in Religion/Sciences Religieuses 36 no. 3-4 (2007): 531 \& 533.

16 Raymond E. Brown, "The Sensus Plenior in the Last Ten Years," Catholic Biblical Quarterly 25 (1963): 268-69

17 Matthew Dunn, "Raymond Brown,” 544; cf. William Sanford LaSor, "Prophecy, Inspiration, and Sensus Plenior," Tyndale Bulletin 29 (1978), $49-60$.

18 Virkler \& Ayayo, Hermeneutics: principles and processes of Biblical interpretation 26.

19 Ramm, Protestant Biblical Interpretation, 122, 146
} 
them symbolically." 20

\section{Spiritual Factors in the Perceptual Process}

The fourth controversial issue in contemporary hermeneutics is whether spiritual factors affect the ability to accurately perceive the truths contained in Scripture. Scripture itself teaches that spiritual commitment, or lack of it, influences the ability to perceive spiritual truth. ${ }^{21}$ In distinguishing between the regenerate and the unregenerate interpreter, Buddeus says, the unregenerate lack two things: 1 . Agreement with that which transcends human reason, and 2, the vitality of the word of Scripture. ${ }^{22}$ Calvin established that only persons inwardly taught by the Holy Spirit take their stand clearly and securely on the Bible. ${ }^{23}$ Hermeneutics should not be a process attempt to use only human knowledge to unravel the author's intention, neither should it be a process that ignores a systematic approach.

\section{The Question of Inerrancy}

Of all the controversial issues with implications for hermeneutics, biblical inerrancy is widely debated. ${ }^{24}$ The primary debate is between the stance of full inerrancy and that of limited inerrancy; Virkler \& Ayayo claim that full inerrancy affirms that the original manuscripts of Scripture are without error in the things they assert. Limited inerrancy affirms that Scripture is without error in matters of faith and practice but may include errors on matters such as history, geography, or science. ${ }^{25}$ Grudem simply defines inerrancy as "the Bible always tells the truth," and that it always tells the truth "concerning everything it talks about."26

\section{LITERALIST INTERPRETATION}

A literalist is someone who applies a literal approach to the interpretation of the Scriptures. The basic concept of Biblical literalism is that the Bible means what it says; and it clearly communicates truth and instruction from God to humans. Literal interpretation asserts that a biblical text is to be interpreted according to the "plain meaning" conveyed by its grammatical construction and historical context. Hence, the literal meaning is held to correspond to the intention of the authors. This type of interpretation is often, but not necessarily, associated with belief in the verbal inspiration of the Bible, according to which the individual words of the divine message were divinely chosen. ${ }^{27}$ St. Jerome, an influential $4^{\text {th }}$-century biblical scholar, championed the literal interpretation of the Bible in opposition to what he regarded as the excesses of allegorical interpretation. ${ }^{28}$ During each of the foregoing periods, a literalist strand of interpretation insisted on a purer, more pristine, less fanciful approach to the Bible..$^{29}$ Literal interpretation recognizes nuances, metaphors, similes hyperbole, symbolism, plays on words, or the various figures of speech that the biblical writers frequently use.

\section{Grammatical-Historical Method}

This method suggests that the meaning of a text is the author's intended meaning and that the author's intention can be derived most accurately by observing the facts of history and the rules of grammar as they apply to the text being studied..$^{30}$ The Christians practicing this approach believe that the Bible is to be interpreted literally unless the language of a particular passage is metaphorical. ${ }^{31}$ The school of Antioch was known for its literal and historical method of interpretation. $^{32}$

The advantage of the literal or historical-grammatical interpretation is that it is the method usually practised in the interpretation of literature. It also seeks authorial intent. It controls the exegete from falling prey to common abuses of Scripture - mystical and allegorical interpretation. It also takes into consideration the historical background, as the

\footnotetext{
20 Virkler \& Ayayo, Hermeneutics: principles and processes of Biblical interpretation 27.

21 Romans 1:18-22; 1 Corinthians 2:6-14; Ephesians 4:17-24; 1 John 2:11

22 Johannes Reinhard, Die Prinzipienlehre der lutherischen Dogmatik von 1700 bis 1750 (Hollatz, Buddeus, Mosheim), Leipzig, 1906,52 cited in Gerhard Maier, 53

23 Inst I, 7, 5. Cf. the entire context of INst I, 2-8. cited in Gerhard Maier, 53; Cf. Roy Zuck, "The Role of the Holy Spirit in Hermeneutics," Bibliotheca Sacra 141 (1984): 120-30; cf., J. C. K. v. Hofmann, Biblische Hermeneutik. Edited by W. Volck, (Nordlingen, 1880$) 101$ cited in Gerhard Maier, 54.

24 Wayne Grumen, Systematic Theology: An Introduction to Biblical Doctrine (Grand Rapids: Zondervan, 1994), 90-104; Millard J. Erickson, Christian Theology, $2^{\text {nd }}$ ed. (Grand Rapids: Baker, 1998), 246-65.

25 Virkler \& Ayayo, Hermeneutics: principles and processes of Biblical interpretation 29.

26 Grumen, Systematic Theology 91.

27 Encyclopaedia Britannica, “Hermeneutics: Principles of Biblical Interpretation,” accessed on April 16, 2020. https://www.britannica.com/topic/hermeneutics-principles-of-biblical-interpretation.

28 Encyclopaedia Britannica, "Hermeneutics: Principles of Biblical Interpretation,".

29 Roubert A. Coughenour, "The Shape and Vehicle of Puritan Hermeneutic", Reformed Review, Vol. 30 No. 1 (1976), 23-34

30 Virkler and Ayayo, Hermeneutics: principles and processes of Biblical interpretation 77.

31 Milton S. Terry, Biblical Hermeneutics, $2^{\text {nd }}$ ed. (Grand Rapids: Zondervan, n.d.), 205 cited in Robert L. Thomas, “The Principle of Single Meaning," TSMJ 12/1 (Spring 2001) 33-47.

32 Francis Young, Alexandrian and Antiochenes Exegesis, In Alan J. Hauser and Duane F. Watson (eds), A History of Biblical Interpretation: The Ancient Period, (vol. 1), (Grand Rapids, MI: Eerdmans, 2003), 334-354; cf.,Virkler and Ayayo, Hermeneutics: principles and processes of Biblical interpretation 73.
} 
Scripture was written within human history. To Luther, "that is the true method of interpretation which puts Scripture alongside of Scripture in a right and proper way"33

\section{FUNDAMENTALIST INTERPRETATION}

Fundamentalists are traditionally referred to as followers of Christ who believe that the Bible is the inspired Word of God and so believe in its literal interpretation and fundamental teachings. ${ }^{34}$ Borg defines a fundamentalist as an evangelical who generally "interprets the Bible literalistically," ${ }^{35}$ and these readings focus most often on "legalistic morality and eschatology." 36

Fundamentalism was a movement that had its roots in revivalism; it came to dominance in North America in the early decades of the twentieth century. In the $1850 \mathrm{~s}$, conservative Baptist preachers spoke out against the tide of progressive, liberal theology and the practice of some Baptist churches in accepting pedobaptism and pulpit affiliation with other denominations. This brought about the birth of Southern Baptist fundamentalists.According to Barr, there are a number of key elements that provide the culture in which fundamentalism grows:

"A strong sense of sin; the need for personal salvation; faith in Jesus as one's personal Saviour; a conviction that the most so-called Christians are only Christians in name and need to be born again; and the tendency to be conservative in opposing all sorts of modern ideals and modes of interpreting the Bible...this is the culture. But the key defining principle of fundamentalism is the absolute centrality of the Bible, as well as its complete inerrancy and infallibility"37

Fundamentalists use the model of prophetic oracles ("Thus says the Lord") to cover every book in the Bible and conclude that every single word of the Bible comes directly from God. ${ }^{38}$ It is unmistakable that at the core fundamentalism was first and foremost a theological response to modernism. ${ }^{39}$ Barr makes the point that fundamentalism is reactionary and aggressive, rather than truly conservative..$^{40}$ In their interpretation, they may still maintain that the earth is flat despite the scientific evidence of roundness. Barr, convincingly concludes by saying:

The Bible must be so interpreted as to avoid any admission that it contains any kind of error. In order to avoid imputing error the Bible fundamentalists will twist and turn back and forward between literal and non-literal interpretations...in particular by abandoning the literal sense as soon as it would be an embarrassment to the view of inerrancy held. ${ }^{41}$

Fundamentalists, are very sensitive to personal sin but are so lacking in self-criticism as to appear unaware of the role of $\sin$ in their intransigent positions, and in their treatment of those who do not share their views. ${ }^{42}$

Fundamentalism holds to the letter of Scripture and can be somewhat pharisaic. ${ }^{43}$ Hodges observes that "the literalist approach of fundamentalism can lead us both to misread scripture and think that our own culture is part of the gospel message." ${ }^{\prime 4}$ According to Canale, the fundamentalist method of interpretation contains at least two basic flaws. Firstly, "it encourages the notion that serious study or reflection is unnecessary to understand the Bible." ${ }^{55}$ Secondly, "because of this miraculous view of illumination, believers are bound to confuse their partial and incorrect interpretations of Scripture with God's will for the entire human race." 46

\section{BIBLICAL INERRANCY}

This is the identifying tag of the fundamentalists. Biblical inerrancy refers to the view that the Bible is "free from all

\footnotetext{
33 Luther, Works, Philadelphia Edition, Vol. III. 334 cited in Ralph Drollinger, "Hermeneutics: Can You Make the Bible Say What You Want?" Capitol Ministries (2018): 1-8.

34 Dale A. Robbins, “fundamentalist Christian”, https://www.victorious.org/cbook/chur21-fundamentalist-christian. Cf., Sandra M. Schneiders, "God's Word for God's people", The Bible Today, (1984): 100-107.

35 Fidon R. Mwombeki, "Reading the Bible in Contemporary Africa" Word \& World, XXI, no. 2, (2001): 121-28.

36 Mwombeki, "Reading the Bible in Contemporary Africa" 125.

7 James Barr, Fundamentalism (London: SCM Press, 1977) 313.

8 Michael Fallons, Fundamentalism: A Misunderstanding of Religious Experience, (1992) 4

39 C. Norman Kraus, Dispensationalism in America: its Rise and Development (Richmond, VA: John Knox Press, 1958), 45; Kraus, "Evangelism: The Great Evangelical Coalition,"55; Ernest R. Sandeen, The Origins of Fundamentalism: Toward a Historical Interpretation (Philadelphia: Fortress Press, 1968), 2-3; George M. Marsden, Fundamentalism and American Culture, (New York: Oxford University Press, 1980),3 Marsden, Understanding Fundamentalism and Evangelicalism, (Grand Rapids, MI: Eerdmans Publishing Company, 1991), 2.

40 Barr, Fundamentalism, 173.

41 Barr, Fundamentalism,40-46.

42 Barr, Fundamentalism, 178.

43 David William Faupel in The everlasting Gospel, (Sheffield Academic Press, 1996), 50, describes the rise of fundamentalism in nineteenth century America; William Loader, Jesus and the Fundamentalism of His Day (Grand Rapids: Eerdmans, 2001) in which he showed Jesus more interested in people than a legal code.

44 Kent Hodges, "Jesus the Shepherd Leader: New Covenant Hermeneutics and issues for Christian leadership" Inner Resources for Leaders, School of Global Leadership \& Entrepreneurship, Regent University, 7, accessed April 24, 2020. https://www.regent.edu/acad/global/publications/innerresources/vol2iss3/hodge.pdf.

45 Fernando Canale, The Cognitive Principle of Christian Theology: A Hermeneutical Study of the Revelation and Inspiration of the Bible, (Berrien Springs, MI: Andrews University Press, 2010), 210.

46 Canale, The Cognitive Principle of Christian Theology,210.
} 
falsehood, fraud, or deceit." ${ }^{\prime 47}$ In other words, according to Scripture whatever wilfully misleads or deceives is false. ${ }^{48}$ Of course, on such a view there can be factual inadequacies in the text of Scripture, but so long as the interpreter determines that the writer did not intend to deceive the reader, no rejection of inerrancy is legitimate. ${ }^{49}$

\section{CONVERGENCE}

This school of thought also believes in the authority of the Bible. They see themselves as affirming the old-time religion, they criticize moderate-to-liberal Christians for watering down the authority of the Bible, and they exist as a reactant to a modern interpretation of the Bible.

\section{DIVERGENCE}

Fundamentalists ignore the cultural fact though supposedly committed to literal hermeneutics.The problem of fundamentalism is not that it takes the literal truth of the Bible as inerrant, but that it fails to discern what that literal truth is, because, among other things, it fails to realize the need for literary and historical criticism. ${ }^{50}$ Fallons concludes that the great enemy of fundamentalism is the scientific study of the Bible....and attempts to find its meaning in its own historical and literary terms. ${ }^{51}$ It should be obvious that even in evangelicalism which is so committed to literal hermeneutics, that commitment does not always give the same results when applied to a concrete passage or theological issue. $^{52}$

Ultimately, no particular hermeneutical "method" can guarantee a better understanding of and obedience to Holy Scripture. An openness of heart and a searching mind remains essential (Psalm 119:18). ${ }^{53}$ The emergence of the higher criticism movement which challenged the Bible stories as little more than mythology, subjecting miracles in the Bible to scientific evaluation and studying the Bible as literature rather than divine revelation hits hard on the foundation of biblical literalism. The dichotomy between science and religion will continue as the literalist-fundamentalist approach does not give room for scientific imposition of biblical interpretation. As much as many Christians or biblical scholars will feel comfortable with the literalist approach, based on opening to the grammatical and historical context of the text, they may not go with the fundamentalist (strict literalist or inerrant) approach. The fundamentalist's reason that inerrancy of Scripture means that everything in the Bible must be literally, absolutely, grammatically, historically and scientifically true. Hence, the apparent conflict between the Bible and another source, such as history or science would go in favour of the Bible, because of its inerrancy.

\section{CONCLUSION}

The interpretation of the Bible should go beyond an apologetic approach against attacks on its Divine origin and accuracy. However, the debates should center on how much of the Bible texts should be interpreted literally. Humility should be employed in the study of the Bible in accepting and rejecting "new truth". The Biblical teachings, such as parables, proverbs and miracles; conveys the divine message for Christians whether taken literally or not. A large part of the Bible makes sense when read literally and it exercises control on the human imagination.

\section{ABOUT AUTHOR}

Alu,Caleb Olayiwola, MABTS is a PhD Candidate at the Department of Religious Studies, Adeleke University, Ede. Nigeria.

\section{BIBLIOGRAPHY}

Allen, Stuart, The interpretation of Scripture, London: The Berean Publishing, 1967.

Andrew, S. L., "Biblical Inerrancy," Chafer Theological Seminary Journal 8, no 1 (2002):1-20

Barr, James, Fundamentalism, London: SCM Press, 1977.

Berkhof, L., Principles of Biblical Interpretations, Grand Rapids: Baker House, 1969.

\footnotetext{
47 Stephen L. Andrew, "Biblical Inerrancy," Chafer Theological Seminary Journal, 8, 2-21; cf., Gerrit C. Berkouwer, Holy Scripture: Studies in Dogmatics (Grand Rapids:Eerdmans, 1975) 182-184; S. T. Davis, The Debate About the Bible (Philadelphia: Westminster, 1977; D. Fuller, "Benjamin B. Warfield's View of Faith and History," Bulletin of the Evangelical Theological Society (BETS) 11 no.2 (1968): 75-83, Cited In Feinberg, John S, “Truth, Meaning and Inerrancy in Contemporary Evangelical Thought" JETS 26 no.1 (1983):17-30.

48 Paul D. Feinberg, “The Meaning of Inerrancy,” Inerrancy (ed. N. L. Geisler; Grand Rapids: Zondervan, 1979) 287 cf. David Hubbard, “The Current Tensions: Is There a Way Out?" Biblical Authority (ed. J. Rogers; Waco: Word, 1977).

49 Feinberg, "Truth, Meaning and Inerrancy."

50 Fallons, Fundamentalism, 11.

Fallons, Fundamentalism, 29.

52 John S. Feinberg, "Truth, Meaning and Inerrancy in Contemporary Evangelical Thought," JETS 26/1 (March 1983) 17-30

3 Hans K. LaRondelle,’Trends in Biblical Hermeneutics (Part 2 0f 2)” Ministry: International Journal for Pastors, (November 2010), 11-14
} 
Berkouwer, G. C., Holy Scripture: Studies in Dogmatics, Grand Rapids: Eerdmans, 1975.

Borg, Marcus J., Reading the Bible Again for the First Time: Taking the Bible Seriously but not Literally, New York City: HarperCollins Publishers, 2001

Brown, Raymond Edward, "The Sensus Plenior in the Last Ten Years," Catholic Biblical Quarterly 25, (1963): 268-269 The Sensus Plenior of Sacred Scripture, Eugene: Wipf \& Stock, 2008.

Canale, Fernando, The Cognitive Principle of Christian Theology: A Hermeneutical Study of the Revelation and Inspiration of the Bible, Berrien Springs: Andrews University Press, 2010.

Coughenour, Roubert A., 1976, "The Shape and Vehicle of Puritan Hermeneutic", Reformed Review, Vol. 30 no 1 (1976): 23-34

Davis, S. T., The Debate About the Bible, Philadelphia: Westminster, 1977.

Drollinger, Ralph, "Hermeneutics: Can You Make the Bible Say What You Want?" Capitol Ministries (June 4, 2018): $1-8$.

Dunn, James D. G., The Partings of the Ways: Between Christianity and Judaism and Their Significance for the Character of Christianity, Philadelphia: Trinity Press International, 1991. https://doi.org/10.1017/s0036930600045440

Dunn, Matthew, "Raymond Brown and the Sensus Plenior Interpretation of the Bible," Studies in Religion/Sciences Religieuses 36 no. 3-4 (2007): 531-551. https://doi.org/10.1177/000842980703600306

Encyclopaedia Britannica, "Hermeneutics: Principles of Biblical Interpretation,”Accessed April 16, 2020. https://www.britannica.com/topic/hermeneutics-principles-of-biblical-interpretation.

Erickson, Millard J., Christian Theology, (2 ${ }^{\text {nd }}$ ed.), Grand Rapids: Baker, 1998.

Fallons, Michael, Fundamentalism: A Misunderstanding of Religious Experience, (1992). Accessed July 12, 2020 http://mbfallon.com/fundamentalism book.pdf

Faupel, William D., The everlasting Gospel, Sheffield: Sheffield Academic Press, 1996.

Feinberg, John S, "Truth, Meaning and Inerrancy in Contemporary Evangelical Thought" JETS 26 no 1 (March 1983): 17-30.

Feinberg, P. D., “The Meaning of Inerrancy,” in N. L. Geisler (ed.), Inerrancy, Grand Rapids: Zondervan, 1979.

Fuller, Daniel, "Benjamin B. Warfield's View of Faith and History," Bulletin of the Evangelical Theological Society (BETS) 11 no 2 (Spring 1968): 75-83.

Grumen, Wayne, Systematic Theology: An Introduction to Biblical Doctrine, Grand Rapids: Zondervan, 1994.

Hirsch, E. D., Validity in Interpretation, New Haven: Yale University Press, 1967.

Hodges, Kent, (n.y), "Jesus the Shepherd Leader: New Covenant Hermeneutics and issues for Christian leadership" Inner Resources for Leaders, School of Global Leadership \& Entrepreneurship, Regent University, Accessed April 24, 2020.

https://www.regent.edu/acad/global/publications/innerresources/vol2iss3/hodge.pdf

Hubbard, D, “The Current Tensions: Is There a Way Out?” in, J. Rogers (ed.), Biblical Authority, Waco: Word, 1977.

Jeanrond, W. G., "Hermeneutic." A Dictionary of Biblical Interpretation, in R. J. Coggins and J. L. Houlden (Eds.), Philadelphia: Trinity Press, 1990.

Kaiser Jr, Walter C. \& Silva, Moises, Introduction to Biblical Hermeneutics: The Secret for Meaning, (rev. and exp.), Grand Rapids: Zondervan, 2007.

Kraus, C. Norman, Dispensationalism in America: its Rise and Development, Richmond: John Knox Press, 1958.

LaRondelle, Hans K., "Trends in Biblical Hermeneutics (Part 2 of 2)" Ministry: International Journal for Pastors, (November 2010): 11-14.

LaSor, William Sanford, "Prophecy, Inspiration, and Sensus Plenior," Tyndale Bulletin 29 (1978): 49-60.

Loader, William, Jesus and the Fundamentalism of His Day, Grand Rapids: Eerdmans, 2001.

Maier, Gerhard, Biblical Hermeneutics, translated by Robert W. Yarbrough, Wheaton: Crossway, 1994.

Marsden, George M., Fundamentalism and American Culture, New York: Oxford University Press, 1980.

Marsden, George M., Understanding Fundamentalism and Evangelicalism, Grand Rapids: Eerdmans Publishing Company, 1991.

Mwombeki, Fidon R., "Reading the Bible in Contemporary Africa" Word \& World, volume XXI, Number 2, (spring 2001): 121-28.

Oladejo, Olusayo B., "Biblical hermeneutics and decision-making: A critique of the dispensationalist approach." International Journal of Current Research, 8, no 02 (2016) 27039-27043.

Osborne, Grant R., The Hermeneutical Spiral: A Comprehensive Introduction to Biblical Interpretation ( $2^{\text {nd }}$ ed.), Downers Grove: InterVarsity Press, 2006.

Ramm, Bernard, Protestant Biblical Interpretation, Boston: W. A. Wilde Company, 1956.

Ricoeur, Paul, “The Hermeneutical Function of Distanciation.” PhTod 17 (1973): 112-141. 
Robbins, Dale A., "Fundamentalist Christian", Accessed July 12, 2020.

https://www.victorious.org/cbook/chur21-fundamentalist-christian

Sandeen, Ernest R., The Origins of Fundamentalism: Toward a Historical Interpretation, Philadelphia: Fortress Press, 1968.

Schneiders, Sandra M.,"God's Word for God's people”, The Bible Today, (March 1984): 100-107.

Terry, Milton S., Biblical Hermeneutics: A treatise on the interpretation of the Old and New Testaments. New York: Phillips \& Hunt, 1885.

Thomas, Robert L.,"The Principle of Single Meaning,” TSMJ 12 no 1 (Spring 2001): 33-47.

Virkler, Henry A., \& Karelynne Gerber Ayayo, Hermeneutics: principles and processes of Biblical interpretation $\left(2^{\text {nd }}\right.$ ed.), Grand Rapids: Bakers Academic, 2007.

Yarchin, William, History of Biblical Interpretation: A Reader, Grand Rapids: Baker Academic, 2011.

Young, F., Alexandrian and Antiochenes Exegesis, In Alan J. Hauser and Duane F. Watson (eds), A History of Biblical Interpretation: The Ancient Period, (vol. 1), Grand Rapids: Eerdmans, 2003.

Zuck, Roy, “The Role of the Holy Spirit in Hermeneutics,” Bibliotheca Sacra 141 (1984): 120-130. 